\title{
Viable Tumor Tissue Adherent to Needle Applicators after Local Ablation: A Risk Factor for Local Tumor Progression
}

\author{
Nikol Snoeren ${ }^{1}$, Joost Huiskens ${ }^{2}$, Arjen M. Rijken, MD $^{3}$, Richard van Hillegersberg, MD ${ }^{1}$, Arian R. van Erkel ${ }^{4}$, \\ Gerrit D. Slooter, $\mathrm{MD}^{5}$, Joost M. Klaase, $\mathrm{MD}^{6}$, Petrousjka M. van den Tol, $\mathrm{MD}^{7}$, Fibo J. W. Ten Kate, $\mathrm{MD}^{2}$, \\ Maarten C. Jansen, $\mathrm{MD}^{2}$, and Thomas M. van Gulik, $\mathrm{MD}^{2}$ \\ ${ }^{1}$ University Medical Centre Utrecht, Utrecht, The Netherlands; ${ }^{2}$ Department of Surgery, Academic Medical Centre, \\ Amsterdam, The Netherlands; ${ }^{3}$ Amphia Hospital, Breda, The Netherlands; ${ }^{4}$ Leiden University Medical Centre, Leiden, \\ The Netherlands; ${ }^{5}$ Maxima Medical Centre, Veldhoven, The Netherlands; ${ }^{6}$ Medisch Spectrum Twente, Enschede, Medisch \\ Spectrum Twente; ${ }^{7}$ VU Medical Centre, Amsterdam, The Netherlands
}

\begin{abstract}
Background. Local tumor progression (LTP) is a serious complication after local ablation of malignant liver tumors, negatively influencing patient survival. LTP may be the result of incomplete ablation of the treated tumor. In this study, we determined whether viable tumor cells attached to the needle applicator after ablation was associated with LTP and disease-free survival.

Methods. In this prospective study, tissue was collected of 96 consecutive patients who underwent local liver ablations for 130 liver malignancies. Cells and tissue attached to the needle applicators were analyzed for viability using glucose-6-phosphate-dehydrogenase staining and autofluorescence intensity levels of $\mathrm{H} \& \mathrm{E}$ stained sections. Patients were followed-up until disease progression.

Results. Viable tumor cells were found on the needle applicators after local ablation in $26.7 \%$ of patients. The type of needle applicator used, an open approach, and the omission of track ablation were significantly correlated with viable tumor tissue adherent to the needle applicator. The presence of viable cells was an independent predictor of LTP. The attachment of viable cells to the needle applicators was associated with a shorter time to LTP.

Conclusions. Viable tumor cells adherent to the needle applicators were found after ablation of $26.7 \%$ of patients. An independent risk factor for viable cells adherent to the
\end{abstract}

(C) The Author(s) 2011. This article is published with open access at Springerlink.com

First Received: 9 June 2010;

Published Online: 18 May 2011

T. M. van Gulik, MD

e-mail: T.M.vanGulik@amc.uva.nl needle applicators is the omission of track ablation. We recommend using only RFA devices that have track ablation functionality. Adherence of viable tumor cells to the needle applicator after local ablation was an independent risk factor for LTP.

The most effective treatment for patients with primary or metastatic liver tumors confined to the liver is surgical resection. ${ }^{1,2}$ Because of improvements of imaging techniques, expanded surgical possibilities, and effective neoadjuvant treatment, liver resection is nowadays applicable in an increasing amount of patients. Nevertheless, the majority of patients with primary or metastatic hepatic malignancies are unresectable. Local tumor destruction by radiofrequency ablation (RFA) or laser-induced thermal therapy (LITT) has proven to be a safe and effective treatment in patients with unresectable liver malignancies. $^{3-7}$ Reported 5-year survival rates after local ablation are $18-30 \%$ for tumors smaller than $4 \mathrm{~cm}^{8-19}$

A major downside of RFA is local tumor progression (LTP), which varies from $0-60 \%$ in literature. , $^{3,50-23}$ Large tumor size and a percutaneous approach have been reported with a higher incidences of LTP according to a meta-analysis of 5,224 treated liver tumors treated with RFA. ${ }^{23}$ LTP usually is the result of incomplete ablation of the treated tumor. Repositioning or withdrawal of the needle applicator with insufficiently treated tumor cells might cause implantation and outgrowth of tumor cells along the tract of the needle applicator. Previously, Ohlsson et al. ${ }^{24}$ demonstrated the implantation and outgrowth of tumor cells in $1 \%$ of patients with $\mathrm{HCC}$ and $10 \%$ of patients with colorectal liver metastases after fine needle 
biopsy. In a previous paper on 40 patients who underwent local ablation, we observed that tumor tissue was macroscopically visible on the needle applicator after $53 \%$ of all applications, demonstrating displacement of tissue through the liver during and after local ablation. Remarkably, $12.5 \%$ of the tumor cells attached to the needle applicator were viable immediately after local tumor ablation. ${ }^{25}$ Therefore, we hypothesized that tumor dissemination through attached viable cells on the needle applicator and subsequent outgrowth of these cells along the needle applicator track potentially threatens patient survival after local ablation.

The purpose of this study was to determine the incidence of viable tumor cells attached to needle applicators after ablation and to assess whether the presence of viable tumor cells correlated with LTP and disease-free survival (DFS).

\section{MATERIAL AND METHODS}

Needle applicators were collected after local ablation of 130 malignant liver tumors in 96 consecutive patients. All 130 liver malignancies of primary or secondary origin were treated between November 2004 and November 2006 among seven centers in the Netherlands. The study protocol was approved by the institutional ethical committees on human research. Patients underwent standard staging before treatment, including computed tomography of the abdomen. All patient, tumor, and ablation characteristics were prospectively collected using case report forms during and after ablation and transferred to our prospective database.

\section{Inclusion Criteria}

Patients with unresectable primary or metastatic tumors confined to the liver as decided by the surgeon and/or radiologist were considered for this study. Patients 18 years or older who were amenable to RFA or LITT treatment were included in the study.

\section{Exclusion Criteria}

Patients younger than 18 years, patients unfit for surgery, patients with tumors adjacent to or infiltrating large vessel(s), or patients with extrahepatic disease were excluded.

\section{RFA/LITT PROCEDURE}

In all treated tumors, the RFA electrode or laser fiber was positioned in the centre of the tumor under ultrasound or CT guidance with the goal to induce necrosis with a circumferential necrotic rim of $0.5-1.0 \mathrm{~cm}$. If necessary, multiple overlapping applications were performed. RFA was performed using three different commercially available RFA systems: the Radionics RF system (Covidien, Mansfield, MA) consisting of a 500-kHz RF generator connected to 15-G Radionics cool-tip mono- or tripleneedle applicator varying from 2 to $3 \mathrm{~cm}$ in active tip (series 3 Radionics); the Radiotherapeutics RF system (Natick, Boston Scientific MA) inducing a RF 2000 or 3000 generator system in combination with a $15-\mathrm{G}$ LeVeen needle applicator with deployable tines of $2.5-4 \mathrm{~cm}$; and the RITA RF system (RITA Medical Systems, Mountain View, CA) consisting of the RITA RF model 1500 connected to a 14-G Starbust XL needle applicator with deployable tines of $2,3,4$, or $5 \mathrm{~cm}$.

LITT was applied using a neodymium:yttrium-aluminum-garnet (Nd:YAG) laser (Trumpf Medizine Systeme, Umkirch, Germany) with a wavelength of 1,064 nm. All surgeons preferred an open approach. A percutaneous RFA/LITT was performed when the patient was not in sufficient condition to undergo open surgery or had a small easy accessible tumor. One center preferred percutaneous RFA above open RFA. This center used CT guidance for positioning of the needle applicator and subsequent control of the ablation zone after RFA.

\section{TISSUE COLLECTION}

RFA electrodes and laser fibers were inspected immediately after retraction for the presence of macroscopic tissue fragments. Subsequently, all electrodes and fibers were rinsed and cleaned in a sterile tube containing Complete Williams E (10\% FCS, 1\% Penicillin, Bio Whittaker Europe and $1 \%$ Glutamine, Bio Whittaker Europe), within $10 \mathrm{~min}$ after ablation. During transport, cells were maintained at room temperature. After transportation, the cell suspension was centrifuged for $10 \mathrm{~min}\left(21^{\circ} \mathrm{C}, 50 \mathrm{~g}\right)$. Macroscopic tissue fragments were fixed in $4 \%$ formaldehyde and embedded in paraffin. Sections (3-4 $\mu \mathrm{m})$ were stained with hematoxylin and eosin staining (H\&E staining). Remaining cell suspensions were used for assembling cytospins, which were stained with Papanicolaou (PAP) and Giemsa. Four fortified cytospins were stored at $-80^{\circ} \mathrm{C}$ immediately after use for later viability staining with glucose-6-phosphatedehydrogenase (G6PD). Samples collected later than 10 min after ablation, not collected in Complete Williams, or not processed on the same day were excluded (Fig. 1).

\section{DETERMINATION OF VIABILITY}

\section{Glucose-6-phosphate-diaphorase Staining}

Glucose-6-phosphate-diaphorase is a cytosolic nicotinamide adenine catalyzing the initial step in the hexose 


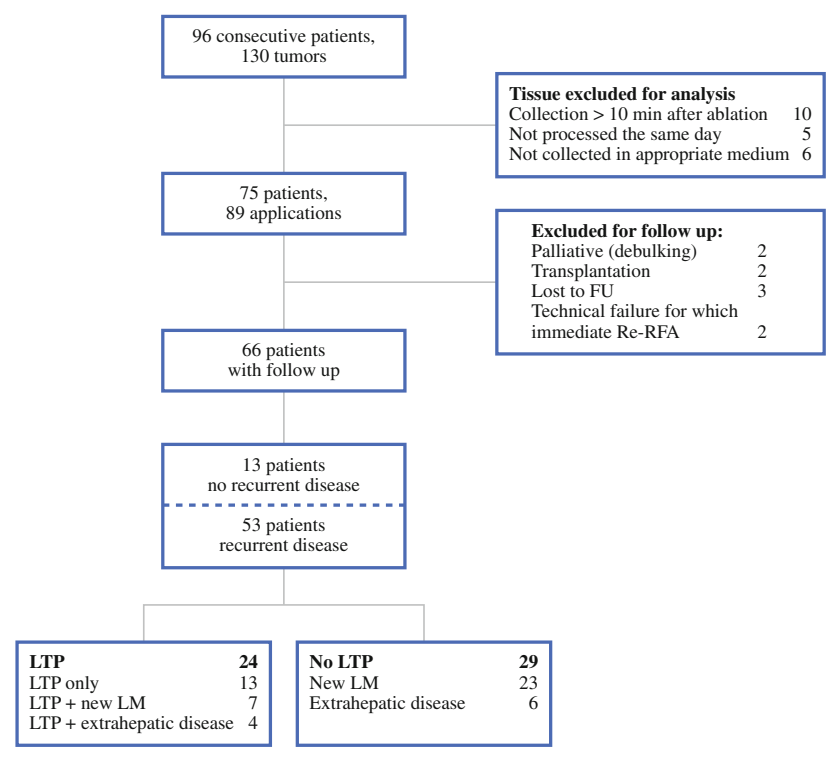

FIG. 1 Flowchart study design

monophosphate shunt oxidizing glucose-6-phosphate to phosphogluconolactone and reducing nicotinamide adenine dinucleotide phosphate (NADP) to NADPH. The hydrogen from reduced NADP reduces the nitro blue tetrazolium (NBT) used forming NBT-formazan which results in a blue color in viable cells. ${ }^{26,27}$ Defrosted cytospins were placed in incubation medium for $15 \mathrm{~min}$ at $37^{\circ} \mathrm{C}$. The incubation medium consisted of $10 \mathrm{mM}$ of glucose- 6 -phosphate, 0.8 of $\mathrm{mM}$ NADP, $5 \mathrm{mM}$ of sodium azide $\left(\mathrm{NaN}_{3}\right), 5 \mathrm{mM}$ of magnesium chloride $\left(\mathrm{MgCl}_{2}\right), 5 \mathrm{mM}, 0.4 \mathrm{mM}$ of 1-methoxyphenazine methosulfate (mPMS), $5 \mathrm{mM}$ of nitro blue tetrazolium (NBT Polyscience, Northampton, UK), and $11 \%$ polyvinyl alcohol (PVA: Sigma-Aldrich, St Louis) containing phosphate buffer ( $\mathrm{pH}$ 7.45). After incubation, slides were washed with $100 \mathrm{mM}$ phosphate buffer for 3 min. Slides were mounted with glycerine and covered with glass. Blue coloration of the cytoplasm indicated viable cells. HepG2 cells were used as positive controls. Incubations of HepG2 cells were performed in the same medium without any substrate (glucose-6-phosphate). Because G6PD is a cytosolic stain, the ratio between nucleus size and cytoplasm size was compared with the sizes in the Giemsa/Pap-stained cytospins of the same application containing tumor cells.

\section{Autofluorescence}

Macroscopic tissue fragments were too small to fortify cryostat sections and were therefore embedded in formalin and fixed in paraffin disabling G6PD viability staining. Because morphologically intact tumor cells might be a result of heat fixation we added an autofluorescence method described by Hennings et al. ${ }^{28}$ to discriminate between heat-fixed tissue and viable tumor tissue. Necrotic cells are known to exhibit increased autofluorescence when excited with light at $488 \mathrm{~nm}$, as cellular autofluorescence increases with decreasing metabolic activity. ${ }^{29-32}$

The study pathologist (FJWtK) determined whether H\&E sections contained intact tumor tissue. All H\&E sections containing intact tumor cells were examined for autofluorescence using $488 \mathrm{~nm}$ wavelengths. To validate the method described by Hennings et al. on tissue of liver tumors, we compared autofluorescence intensities of biopsies containing viable tumor cells from CRLM and HCCs with biopsies with known apoptotic or necrotic cells of CRLM and HCCs. Biopsies were obtained immediately after resection and snap-frozen in liquid nitrogen to maintain viability. H\&E slides were produced and examined under bright-field microscopy using fluorescence microscopy for discrimination of necrotic or heat-fixed tissue and viable tissue. Images were acquired using a Zeiss Axiovert $200 \mathrm{M}$ microscope and Zeiss LSM 510 Software. Unmodified photos were analyzed using the Zeiss LSM 510 Software. Within each image, six random areas were outlined by using the polygon function and individually analyzed. Autofluorescence intensity was determined by using the histogram function. The mean fluorescence intensities with the $95 \%$ confidence interval (CI) of viable tissue fragments $(n=30)$ and of dead tissue fragments $(n=30)$ were determined to define the autofluorescence intensities of viable and dead cells, respectively. Mean autofluorescence intensity of the 30 areas of viable cells was 117 (95\% CI, 80.139-154.02). The maximum intensity measured in the 30 viable spots was 400 . Therefore intensities ranging from 0 to 400 were considered to correspond with viable cells. Mean autofluorescence intensity of the 30 areas that contained nonviable tissue was 1,462 (95\% CI, 1443.78-1480.56).

\section{Follow-up}

Follow-up included abdominal and chest CT scanning within the first month after RFA and thereafter at least every 6 months. Patients with a minimum follow-up of 1 year were included in the survival analysis. Patients who underwent repeated treatment because of technical failure or transplantation within a year after ablation as well as patients receiving adjuvant therapy were excluded from the survival analysis. LTP was defined as tumor growth adjacent to the original ablated tumor on CT scan. Time to LTP was defined as the time between RFA and the first sign LTP. DFS was defined as time between RFA and the first sign of recurrence.

\section{Statistical Analysis}

Univariate analysis using a chi-square test was performed to see if any of the above-mentioned factors were 
associated with the presence of viable tumor cells on the needle applicator. Possible factors related to LTP were examined by using a multivariable logistic regression analysis. Survival time was calculated by using the Kaplan-Meier survival function. A Cox regression analysis was performed to determine risk factors for time to LTP and DFS. For all analyses, $P<0.05$ was considered statistically significant. Statistical analyses were performed using SPSS for Windows version 15.0 (SPSS, Chicago, IL).

\section{RESULTS}

During the study period, tissue was collected after ablation in 96 patients (Fig. 1). In 21 patients, samples did not fulfill the criteria for analysis after ablation. For patient and tumor characteristics, see Table 1. Coagulation of the needle track was not possible in case of the Radiotherapeutics system used in this study (29 of 98 applications). Track ablation also was not used in one other patient treated with LITT because of subcapsular location of the tumor. In all other procedures, track ablation was performed.

Mean tumor size of the treated tumors was $3 \mathrm{~cm}$ (standard deviation 1.8). Vascular inflow occlusion (Pringle maneuver) was used during ablation in 11 of 75 patients $(14.7 \%)$. The Pringle maneuver was used mostly by the surgeon using LITT. This surgeon used the Pringle maneuver in all of nine patients treated. Only two other hospitals used the Pringle maneuver in two cases in which the tumors were adjacent to large hepatic vessels.

\section{Vital Tumor Cells after Local Ablation}

Cytospins stained positive for viable tumor cells in 17 of 89 applications. Thirty-one sections were judged by the study pathologist for presence of morphologically intact tumor cells. Twenty-six sections showed low autofluorescence intensities indicating viable tumor tissue, whereas five tumors demonstrated high autofluorescence intensities indicating heat-fixed cells (Figs. 2, 3). The H\&E slides without morphologically intact cells all demonstrated high $(>1,000)$ autofluorescence levels (results not shown). Of the 75 patients treated, viable tumor cells were found after treatment of 20 patients $(26.7 \%)$. Three factors were associated with adherence of viable tumor cells using a univariate regression model $(P<0.05)$ : $(1)$ the type of electrode used (Radiotherapeutics electrode); (2) an open approach; and (3) the omission of needle track ablation after tumor ablation. The omission of track ablation remained the only independent significant factor associated with viable tumor cells on the needle applicator as determined with a multivariable regression model. There was a
TABLE 1 Patient and tumor characteristics

\begin{tabular}{|c|c|}
\hline Total number of patients & 75 \\
\hline No. of males & $45(60 \%)$ \\
\hline No. of females & $30(40 \%)$ \\
\hline Age (mean; SD) & $65 ; 13.19$ \\
\hline Total number of tumors treated & 118 \\
\hline Tissue collected of tumors & 89 \\
\hline \multicolumn{2}{|l|}{ Tumor histology } \\
\hline $\mathrm{HCC}$ & $18(20.2 \%)$ \\
\hline $\mathrm{LM}$ & $71(79.8 \%)$ \\
\hline \multicolumn{2}{|c|}{ Differentiation primary tumor liver metastases $(n=71)$} \\
\hline Good & $1(1.4 \%)$ \\
\hline Moderate & $54(77.5 \%)$ \\
\hline Poor & $6(8.5 \%)$ \\
\hline Tumor diameter (mean; SD) & $3 \mathrm{~cm} ; 1.8$ \\
\hline \multicolumn{2}{|l|}{ Local ablative technique } \\
\hline RFA & $73(82 \%)$ \\
\hline LITT & $16(18 \%)$ \\
\hline \multicolumn{2}{|l|}{ Tumor localization } \\
\hline Subcapsular & $47(55.3 \%)$ \\
\hline Deep & $38(42.7 \%)$ \\
\hline \multicolumn{2}{|l|}{ Approach } \\
\hline Open procedure & $61(68.5 \%)$ \\
\hline Percutaneous & $28(31.5 \%)$ \\
\hline \multicolumn{2}{|l|}{ Electrode } \\
\hline Radiotherapeutics & $29(32.6 \%)$ \\
\hline RITA & $16(18 \%)$ \\
\hline Radionics & $28(31.5 \%)$ \\
\hline Laser fiber & $16(18 \%)$ \\
\hline \multicolumn{2}{|l|}{ Track ablation } \\
\hline Yes & $56(62.9 \%)$ \\
\hline No & $30(33.7 \%)$ \\
\hline Missing & $3(3.4 \%)$ \\
\hline \multicolumn{2}{|l|}{ Viable cells } \\
\hline Yes & $26(29.2 \%)$ \\
\hline No & $63(70.8 \%)$ \\
\hline
\end{tabular}

$S D$ standard deviation

significant correlation between the use of track ablation and the use of a percutaneous approach (Spearman correlation coefficient $0.393, P=0$ ). When an open approach was used, track ablation was performed in 53\% of applications. When a percutaneous approach was used, track ablation was used in $92 \%$ of applications. There also was a nearly significant correlation between the needle applicator used and the use of track ablation (Spearman correlation coefficient $0.561, P=0.064$ ). Track ablation was applied whenever possible. In two hospitals, the Radiotherapeutics RF system was used. With this system, track ablation was not possible (29 of 89 applications). With one other application, concerning a subcapsular tumor treated with 

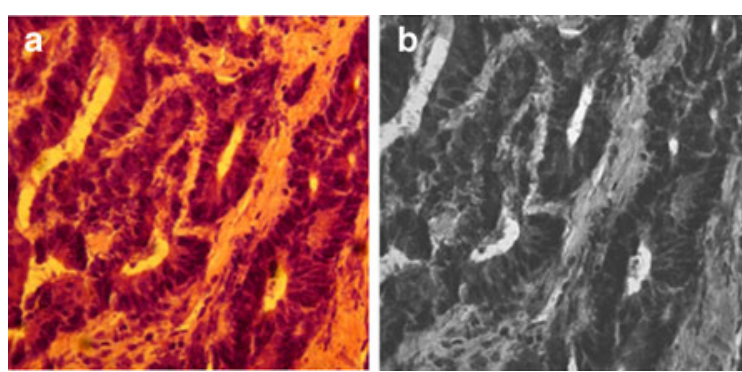

FIG. 2 a HE coupe of morphologically intact tumor cells and stroma. b Black and white image of the same HE coupe, made with confocal microscope without light. c Image of tumorcells excited with
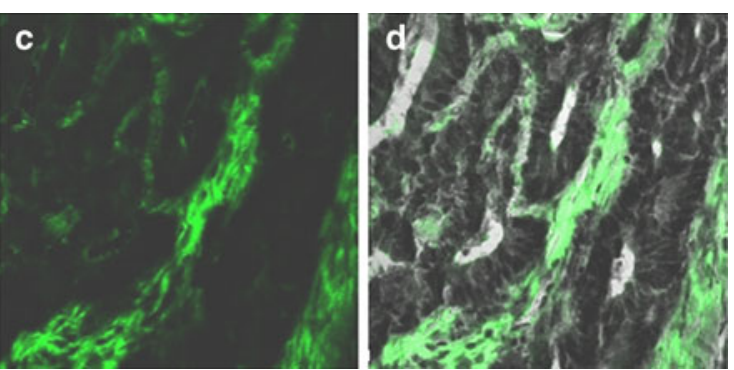

light at $488 \mathrm{~nm}$ showing no autofluoresence (viable). d overlapping image of (b) and (c)

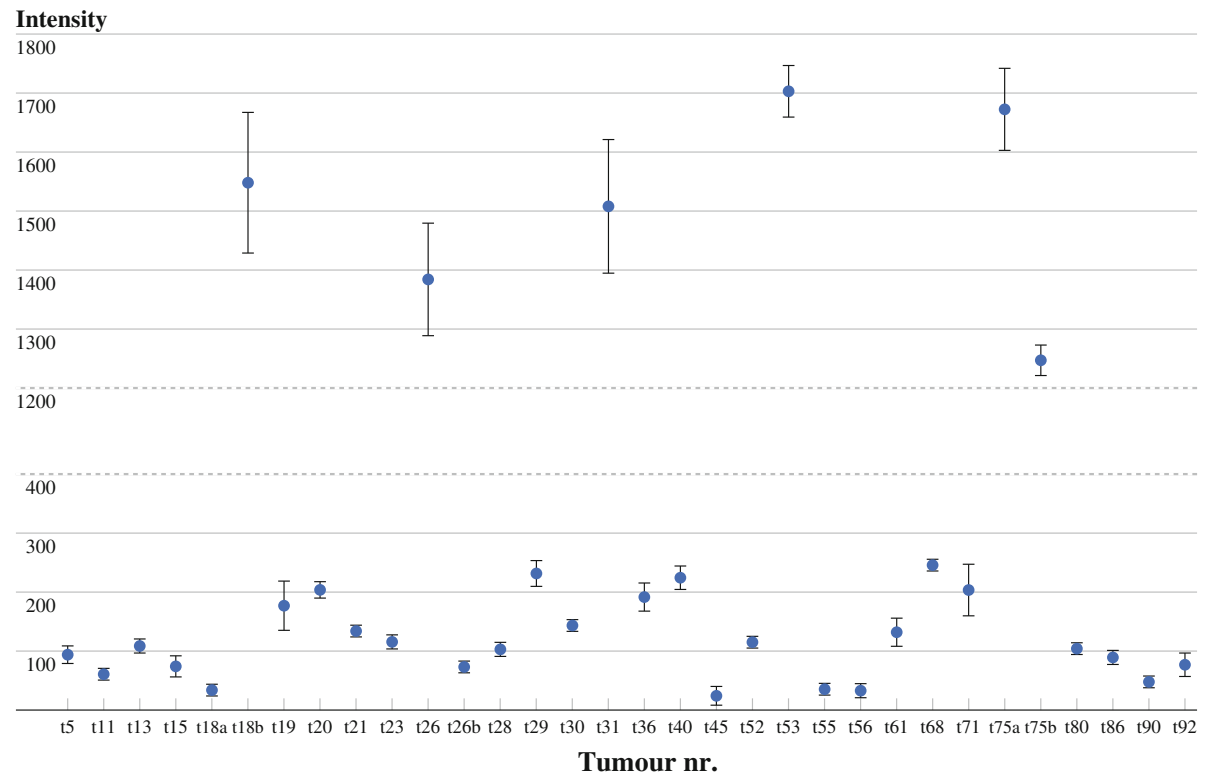

FIG. 3 Level of autofluorescence intensities. Autofluorescence intensities ranging from $0-400$ were considered viable

LITT, track ablation was not applied. In 59\% of applications with the Radiotherapeutics applicator, viable cells were found compared with 19, 11, and $19 \%$ for the RITA, Radionics, and laser, respectively (Tables 2, 3).

\section{$L T P$}

Sixty-four patients had a follow-up of $>1$ year and were included in the survival analysis (Fig. 1). LTP was found in 24 of 66 patients $(36 \%)$. Mean time to LTP was 32.82 (95\% CI, 27.49-37.26) months, whereas DFS was 12.5 (95\% CI, 9.76-15.26).

Tumor size and viable cells attached to the needle applicators were independent risk factors for LTP. Cox regression analysis was used to determine risk factors for time to LTP. Viable cells attached to the needle applicator appeared to be an independent risk factor for a shorter time to LTP. Furthermore, differentiation grade of the primary tumor, tumor size, RFA electrode, and the omission of track ablation were factors associated with a shorter time to LTP in multivariate analysis $(P=0.01,0.028,0.001$, $0.025,0.028$, respectively). The presence of viable cells was not associated with a shortened DFS or overall survival. Mean overall survival in this study was 33 months (Fig. 4).

\section{DISCUSSION}

The majority of patients with liver tumors have unresectable disease. Local ablation permits a chance of 5-year survival in case of small tumors $(<4 \mathrm{~cm})$. LTP is a major problem after local ablative therapies, especially in large tumors, as confirmed by this study demonstrating a local recurrence rate of $38 \% .^{3,5,20-23}$ The local recurrence rate in 
TABLE 2 Analysis of possible risk factors associated with viable tumor cells attached to needle applicators of 89 applications

\begin{tabular}{|c|c|c|}
\hline Risk factors & Vital tumor cells & $P$ \\
\hline \multicolumn{3}{|l|}{ Age (year) } \\
\hline$>65$ & $13 / 42$ & \multirow[t]{2}{*}{0.434} \\
\hline$<65$ & $7 / 33$ & \\
\hline \multicolumn{3}{|l|}{ Gender } \\
\hline M & $11 / 45$ & \multirow[t]{2}{*}{0.605} \\
\hline $\mathrm{F}$ & $9 / 30$ & \\
\hline \multicolumn{3}{|l|}{ Subcapsular } \\
\hline Yes & $15 / 47$ & \multirow[t]{3}{*}{0.637} \\
\hline No & $10 / 38$ & \\
\hline Missing & $1 / 4$ & \\
\hline \multicolumn{3}{|l|}{ Type of tumor } \\
\hline $\mathrm{HCC}$ & $4 / 18$ & \multirow[t]{2}{*}{0.57} \\
\hline Metastasis & $22 / 71$ & \\
\hline \multicolumn{3}{|c|}{ Differentiation of primary tumor } \\
\hline Good & $0 / 1$ & \multirow[t]{5}{*}{0.897} \\
\hline Moderate & $17 / 55$ & \\
\hline Poor & $2 / 6$ & \\
\hline Missing & $0 / 1$ & \\
\hline $\mathrm{HCC}$ & $7 / 26$ & \\
\hline \multicolumn{3}{|l|}{ Needle applicator } \\
\hline Radiotherapeutics & $17 / 29$ & \multirow[t]{4}{*}{0} \\
\hline RITA & $3 / 16$ & \\
\hline Radionics & $3 / 28$ & \\
\hline Laser & $3 / 16$ & \\
\hline \multicolumn{3}{|l|}{ Tumor size } \\
\hline$>4 \mathrm{~cm}$ & $10 / 32$ & \multirow[t]{2}{*}{0.81} \\
\hline$<4 \mathrm{~cm}$ & $16 / 57$ & \\
\hline \multicolumn{3}{|l|}{ Approach } \\
\hline Open & $22 / 61$ & \multirow[t]{2}{*}{0.045} \\
\hline Percutaneous & $4 / 28$ & \\
\hline \multicolumn{3}{|l|}{ Track ablation } \\
\hline Yes & $9 / 58$ & \multirow[t]{2}{*}{0} \\
\hline No & $17 / 31$ & \\
\hline
\end{tabular}

this observational study is high; however, it remains within the reported range in literature (0-60\%). This relatively high rate might be due to the fact that only patients with a minimum follow-up of 1 year were included in the analysis for LTP.

Furthermore, the median follow-up time after ablation was 34 months with five recurrences occurring far beyond a year. Studies with a shorter follow-up period possibly underestimate LTP rate. Another explanation could be that the omission of track ablation was associated with a shorter time to LTP, whereas in our study the rate of procedures performed without track ablation was high. Tumor size also influenced the LTP significantly. Of the patients with a tumor smaller than $3 \mathrm{~cm}, 21 \%$ experienced LTP. Of the patients with tumors larger than $3 \mathrm{~cm}, 64 \%$ experienced LTP.

In this study, we detected viable tissue present on the needle applicator after local ablation in 20 of 75 patients $(26.7 \%)$. Track ablation was the only significant factor in the multivariable regression analysis that significantly correlated with the presence of viable cells. Because track ablation was not possible with the Radiotherapeutics system, this system should be replaced with a system were track ablation is possible.

Viable cells attached to the needle applicator were associated with a higher risk of LTP and a shorter time to LTP. DFS and overall survival were not affected, possibly due to the small number $(n=64)$ of patients available for survival analysis. These results show that local ablative therapies do not always produce enough heat to annihilate all tumor cells, creating a possibility for outgrowth of residual tumor cells. Our study is in line with the results of the study of Sofocleous et al., which demonstrated that examination of tissue attached to the needle applicator is feasible and can be used to predict LTP. In their study, they stained tissue after RFA for HCC with KI-67 and caspase-3 staining. ${ }^{33}$ The immunohistochemical staining characteristics of tumor may be preserved in heat-fixed tissue, therefore, we used the autofluorescence method, which was extensively described by Hennings et al. This method is able to discriminate between heat-fixed tissue and viable tumor tissue. ${ }^{28,34}$ Remarkably, this method showed viable tissue in $26.7 \%$ of patients. The methods used to demonstrate viability of cells in this study are a limitation because they are not easy to apply in daily clinical practice. The protocol for G6PD staining is time-consuming and not all hospitals have the proper equipment for autofluorescence analysis. Our study might very well present an underestimation of the incidence of viable tumor cells retrieved from the needle applicator, because the absence of tumor cells on the needle applicator does not mean that viable tumor cells had not been implanted during the procedure. On the other hand, dislodgement of viable tumor cells does not necessarily mean implantation and outgrowth of these cells in the needle track.

Previous reports that examined needle track implantation after biopsies in CRLM have shown the possibility of outgrowth of displaced tumor cells. ${ }^{24,35,36}$ The finding in this study that attachment of viable cells to the needle applicator was associated with a four times higher risk of LTP and a shorter time to LTP in this study raises serious concerns. Our study underscores the need for more effective tools to assess completeness of local ablative therapies on site to adjust therapy immediately when residual tumor is detected. Track ablation is recommended in literature but does not seem to have been completely implemented in clinical practice as was shown in our study. ${ }^{21,37-40}$ Because 
TABLE 3 Univariate analysis for possible risk factors associated with time to LTP, DFS, OS (months)

\begin{tabular}{|c|c|c|c|c|c|c|}
\hline Risk factors & TLTP $($ mean \pm SD) & $P$ & DFS (mean \pm SD) & $P$ & Overall survival (mean \pm SD) & $P$ \\
\hline \multicolumn{7}{|l|}{ Age } \\
\hline$>65$ & $29.13 \pm 3.59$ & \multirow[t]{2}{*}{0.204} & $11.39 \pm 1.57$ & \multirow[t]{2}{*}{0.676} & $31.86 \pm 2.76$ & \multirow[t]{2}{*}{0.419} \\
\hline$<65$ & $30.22 \pm 3.26$ & & $12.72 \pm 2.51$ & & $30.44 \pm 2.69$ & \\
\hline \multicolumn{7}{|l|}{ Gender } \\
\hline M & $26.65 \pm 2.92$ & \multirow[t]{2}{*}{0.334} & $12.92 \pm 1.83$ & \multirow[t]{2}{*}{0.669} & $31.12 \pm 2.64$ & \multirow[t]{2}{*}{0.896} \\
\hline $\mathrm{F}$ & $35.93 \pm 3.97$ & & $11.68 \pm 2.1$ & & $34.012 \pm 3.08$ & \\
\hline \multicolumn{7}{|l|}{ Subcapsular } \\
\hline Yes & $28.98 \pm 3.28$ & \multirow[t]{2}{*}{0.429} & $10.46 \pm 1.48$ & \multirow[t]{2}{*}{0.142} & $32.35 \pm 2.64$ & \multirow[t]{2}{*}{0.917} \\
\hline No & $35.32 \pm 3.93$ & & $14.54 \pm 2.34$ & & $33.46 \pm 3.16$ & \\
\hline \multicolumn{7}{|l|}{ Type of tumor } \\
\hline $\mathrm{HCC}$ & $34.61 \pm 2.796$ & \multirow[t]{2}{*}{0.09} & $17.75 \pm 4.10$ & \multirow[t]{2}{*}{0.09} & $31.86 \pm 4.59$ & \multirow[t]{2}{*}{0.955} \\
\hline Metastasis & $30.27 \pm 3.066$ & & $10.3 \pm 1.4$ & & $33.58 \pm 2.39$ & \\
\hline \multicolumn{7}{|c|}{ Differentiation of primary tumor } \\
\hline Good & No events & \multirow[t]{4}{*}{0.07} & No events & \multirow[t]{4}{*}{0.01} & 11.11 ( 1 event $)$ & \multirow[t]{4}{*}{0.465} \\
\hline Moderate & $28.33 \pm 4.08$ & & $10.3 \pm 1.29$ & & $33.73 \pm 3.03$ & \\
\hline Poor & $12.11 \pm 3.28$ & & $7.38 \pm 1.42$ & & $19.8 \pm 6.73$ & \\
\hline $\mathrm{HCC}$ & $34.13 \pm 2.99$ & & $17.75 \pm 4.1$ & & $31.86 \pm 4.59$ & \\
\hline \multicolumn{7}{|l|}{ Needle } \\
\hline Radiotherapeutics & $29.54 \pm 4.35$ & \multirow[t]{4}{*}{0.46} & $13.68 \pm 2.52$ & \multirow[t]{4}{*}{0.876} & $32.1 \pm 3.46$ & \multirow[t]{4}{*}{0.344} \\
\hline RITA & $36.23 \pm 6.45$ & & $11.88 \pm 3.38$ & & $39.69 \pm 5.09$ & \\
\hline Radionics & $31.55 \pm 3.92$ & & $12.07 \pm 2.06$ & & $30.49 \pm 3.03$ & \\
\hline Laser & $26.66 \pm 6.23$ & & $11.33 \pm 3.91$ & & $30.96 \pm 5.98$ & \\
\hline \multicolumn{7}{|l|}{ Tumor size } \\
\hline$>4 \mathrm{~cm}$ & $15.25 \pm 3.89$ & 0.001 & $10.98 \pm 3.14$ & 0.663 & $27.94 \pm 4.57$ & 0.203 \\
\hline$<4 \mathrm{~cm}$ & $36.22 \pm 2.96$ & & $12.1 \pm 1.59$ & & $34.49 \pm 2.46$ & \\
\hline Approach & & & & & & \\
\hline Open & $34.91 \pm 3.14$ & 0.219 & $13.52 \pm 1.71$ & 0.228 & $34.34 \pm 2.69$ & 0.443 \\
\hline Percutaneous & $22.71 \pm 3.69$ & & $10.5 \pm 2.35$ & & $27.34 \pm 2.47$ & \\
\hline Pringle & & & & & & \\
\hline Yes & $28.48 \pm 5.65$ & 0.727 & $10.28 \pm 3.26$ & 0.382 & $31.65 \pm 4.81$ & 0.818 \\
\hline No & $32.33 \pm 2.91$ & & $12.94 \pm 1.57$ & & $33.54 \pm 2.34$ & \\
\hline Track ablation & & & & & & \\
\hline Yes & $32.99 \pm 3.39$ & 0.899 & $10.96 \pm 1.76$ & 0.458 & $33.3 \pm 2.75$ & 0.876 \\
\hline No & $30.28 \pm 3.94$ & & $13.75 \pm 2.11$ & & $32.95 \pm 3.06$ & \\
\hline Cells macroscopical & isible & & & & & \\
\hline Yes & $32.97 \pm 3.87$ & 0.907 & $13.31 \pm 2.04$ & 0.543 & $35.18 \pm 3.08$ & 0.404 \\
\hline No & $31.49 \pm 3.45$ & & $11.87 \pm 1.89$ & & $30.79 \pm 2.71$ & \\
\hline Vital cells & & & & & & \\
\hline Yes & $21.19 \pm 3.27$ & 0.038 & $14.01 \pm 2.38$ & 0.323 & $34.75 \pm 3.41$ & 0.538 \\
\hline No & $36.34 \pm 3.09$ & & $11.91 \pm 1.71$ & & $32.45 \pm 2.57$ & \\
\hline
\end{tabular}

Time to LTP, DFS, and OS are calculated with the Kaplan-Meier method

this study demonstrated that viable tissue adheres to the needle applicators used with RFA/LITT, coagulation of needle the track also should be used when the needle applicator is (re)positioned in (viable) tumor during or before the ablative procedure. Moreover, this study shows that viable tumor tissue is found after RFA/LITT even when track ablation is applied, therefore, protocols for track ablation should be executed precisely. 


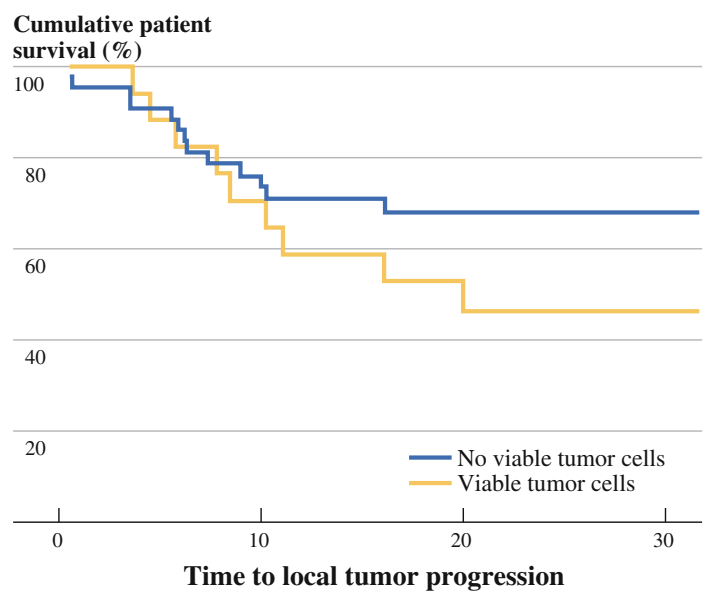

FIG. 4 Kaplan-Meier curves depicting time to local tumor progression in the group with viable tumor cells and without

\section{CONCLUSIONS}

Viable tumor cells adherent to the needle applicators were found in $26.7 \%$ of patients after local tumor ablation. Adherence of viable tumor cells to the needle applicator after local ablation was an independent predictor of LTP. Because the omission of track ablation was the only independent predictor of the presence of viable cells attached to the needle applicator, correct track ablation is mandatory. We recommend only the use of RFA devices with which track ablation can be applied.

ACKNOWLEDGMENT The authors thank Mary de Grauw for her assistance in the histopathologic assessment and Frederik Hoogwater for his assessment of levels of autofluorescence intensities.

OPEN ACCESS This article is distributed under the terms of the Creative Commons Attribution Noncommercial License which permits any noncommercial use, distribution, and reproduction in any medium, provided the original author(s) and source are credited.

\section{REFERENCES}

1. Bruix J, Boix L, Sala M et al. Focus on hepatocellular carcinoma. Cancer Cell. 2004;5:215-9.

2. Boyle P, Ferlay J. Cancer incidence and mortality in Europe, 2004. Ann Oncol. 2005;16:481-8.

3. Solbiati L, Livraghi T, Goldberg SN, et al. Percutaneous radiofrequency ablation of hepatic metastases from colorectal cancer: long-term results in 117 patients. Radiology. 2001;221:159-66.

4. Livraghi T, Solbiati L, Meloni F, et al. Percutaneous radiofrequency ablation of liver metastases in potential candidates for resection: the "test-of-time approach." Cancer. 2003;97:3027-35.

5. Kuvshinoff BW, Ota DM. Radiofrequency ablation of liver tumors: influence of technique and tumor size. Surgery. 2002; 132:605-11.

6. Vogl TJ, Straub R, Eichler K, et al. Malignant liver tumors treated with MR imaging-guided laser-induced thermotherapy: experience with complications in 899 patients (2,520 lesions). Radiology. 2002;225:367-77.
7. Llovet JM, Vilana R, Bianchi L, et al. Radiofrequency in the treatment of hepatocellular carcinoma. Gastroenterol Hepatol. 2001;24:303-11.

8. Aloia TA, Vauthey JN, Loyer EM, et al. Solitary colorectal liver metastasis: resection determines outcome. Arch Surg. 2006;141: 460-6.

9. Berber E, Tsinberg M, Tellioglu G, et al. Resection versus laparoscopic radiofrequency thermal ablation of solitary colorectal liver metastasis. J Gastrointest Surg. 2008;12:1967-72.

10. Gillams AR, Lees WR. Radio-frequency ablation of colorectal liver metastases in 167 patients. Eur Radiol. 2004;14:2261-7.

11. Siperstein AE, Berber E, Ballem N, et al. Survival after radiofrequency ablation of colorectal liver metastases: 10-year experience. Ann Surg. 2007;246:559-65.

12. Veltri A, Sacchetto P, Tosetti I, et al. Radiofrequency ablation of colorectal liver metastases: small size favorably predicts technique effectiveness and survival. Cardiovasc Intervent Radiol. 2008;31:948-56.

13. Hur H, Ko YT, Min BS, et al. Comparative study of resection and radiofrequency ablation in the treatment of solitary colorectal liver metastases. Am J Surg. 2009;197:728-36.

14. Raut CP, Izzo F, Marra P, et al. Significant long-term survival after radiofrequency ablation of unresectable hepatocellular carcinoma in patients with cirrhosis. Ann Surg Oncol. 2005;12:616-28.

15. Lencioni R, Cioni D, Crocetti L, et al. Early-stage hepatocellular carcinoma in patients with cirrhosis: long-term results of percutaneous image-guided radiofrequency ablation. Radiology. 2005;234:961-7.

16. Choi D, Lim HK, Rhim H, et al. Percutaneous radiofrequency ablation for early-stage hepatocellular carcinoma as a first-line treatment: long-term results and prognostic factors in a large single-institution series. Eur Radiol. 2007;17:684-92.

17. Tateishi R, Shiina S, Teratani T, et al. Percutaneous radiofrequency ablation for hepatocellular carcinoma. An analysis of 1000 cases. Cancer. 2005;103:1201-9.

18. Lupo L, Panzera P, Giannelli G, et al. Single hepatocellular carcinoma ranging from 3 to $5 \mathrm{~cm}$ : radiofrequency ablation or resection? HPB (Oxford). 2007;9:429-34.

19. Mahnken AH, Bruners P, Gunther RW. Local ablative therapies in HCC: percutaneous ethanol injection and radiofrequency ablation. Dig Dis. 2009;27:148-56.

20. Abdalla EK, Vauthey JN, Ellis LM, et al. Recurrence and outcomes following hepatic resection, radiofrequency ablation, and combined resection/ablation for colorectal liver metastases. Ann Surg. 2004;239:818-25.

21. Livraghi T, Solbiati L, Meloni MF, et al. Treatment of focal liver tumors with percutaneous radio-frequency ablation: complications encountered in a multicenter study. Radiology. 2003;226: $441-51$.

22. van Duijnhoven FH, Jansen MC, Junggeburt JM et al. Factors influencing the local failure rate of radiofrequency ablation of colorectal liver metastases. Ann Surg Oncol. 2006;13:651-8.

23. Mulier S, Ni Y, Jamart J, et al. Local recurrence after hepatic radiofrequency coagulation: multivariate meta-analysis and review of contributing factors. Ann Surg. 2005;242:158-71.

24. Ohlsson B, Nilsson J, Stenram U, et al. Percutaneous fine-needle aspiration cytology in the diagnosis and management of liver tumours. Br J Surg. 2002;89:757-62.

25. Snoeren N, Jansen MC, Rijken AM, et al. Assessment of Viable Tumour Tissue Attached to Needle Applicators after Local Ablation of Liver Tumours. Dig Surg. 2009;26:56-62.

26. Beutler E. Glucose-6-phosphate dehydrogenase: new perspectives. Blood. 1989;73:1397-401.

27. Van Noorden CJ. Histochemistry and cytochemistry of glucose-6phosphate dehydrogenase. Prog Histochem Cytochem. 1984;15: $1-85$. 
28. Hennings L, Kaufmann Y, Griffin R, et al. Dead or alive? Autofluorescence distinguishes heat-fixed from viable cells. Int $J$ Hyperthermia. 2009;25:355-63.

29. Allwork SP, Bentall HH. Usefulness of the phenomenon of histofluorescence in the identification of early myocardial necrosis. Cardiovasc Res. 1986;20:451-7.

30. Anderson CD, Lin WC, Beckham J, et al. Fluorescence spectroscopy accurately detects irreversible cell damage during hepatic radiofrequency ablation. Surgery. 2004;136:524-31.

31. Chopra P, Sabherwal U. Histochemical and fluorescent techniques for detection of early myocardial ischemia following experimental coronary artery occlusion: a comparative and quantitative study. Angiology. 1988;39:132-40.

32. Salinas-Madrigal L, Sotelo-Avila C. Morphologic diagnosis of acute tubular necrosis (ATN) by autofluorescence. Am J Kidney Dis. 1986;7:84-7.

33. Sofocleous CT, Nascimento RG, Petrovic LM, et al. Histopathologic and immunohistochemical features of tissue adherent to multitined electrodes after RF ablation of liver malignancies can help predict local tumor progression: initial results. Radiology. 2008;249:364-74.

34. Budihardjo I, Oliver H, Lutter M, et al. Biochemical pathways of caspase activation during apoptosis. Annu Rev Cell Dev Biol. 1999; 15:269-90.
35. Rodgers MS, Collinson R, Desai S, et al. Risk of dissemination with biopsy of colorectal liver metastases. Dis Colon Rectum. 2003;46:454-8.

36. Jones OM, Rees M, John TG, et al. Biopsy of resectable colorectal liver metastases causes tumour dissemination and adversely affects survival after liver resection. Br J Surg. 2005;92:1165-8.

37. Lepetit-Coiffe M, Laumonier H, Seror O, et al. Real-time monitoring of radiofrequency ablation of liver tumors using thermaldose calculation by MR temperature imaging: initial results in nine patients, including follow-up. Eur Radiol. 2010;20:193-201.

38. Jaskolka JD, Asch MR, Kachura JR, et al. Needle tract seeding after radiofrequency ablation of hepatic tumors. J Vasc Interv Radiol. 2005;16:485-91.

39. Pacella CM, Bizzarri G, Spiezia S, et al. Thyroid tissue: USguided percutaneous laser thermal ablation. Radiology. 2004;232: 272-80.

40. Jansen MC, Van HR, Chamuleau RA et al (2005) Outcome of regional and local ablative therapies for hepatocellular carcinoma: a collective review. Eur J Surg Oncol. 31:331-47. 